\title{
Copper and copper nanoparticles toxicity and their impact on basic functions in the body
}

\author{
Pohanka M \\ Faculty of Military Health Sciences, University of Defense, Hradec Kralove, Czech Republic. \\ miroslav.pohanka@gmail.com
}

\begin{abstract}
Copper is a biogenic metal having multiple functions in basic processes in organisms and it is common in all kingdoms of life. Limited intake of copper is a problem; however, doses of copper exceeding the recommended alimentary source are problematic as well and toxicity is soon manifested. Impact of copper nanoparticles on human health is another serious issue taken into consideration in this review. Regarding to copper toxicity, neurodegenerative disorders including Alzheimer and Parkinson diseases are suspected to be linked to copper toxicity or copper can contribute to their progression. Wilson and Menke diseases are also described as examples of copper intolerance. This paper is focused on the description, literature survey and discussion of the current knowledge about copper and copper nanoparticles toxicity and their involvement in various pathological processes (Tab. 6, Fig. 2, Ref. 171). Text in PDF www.elis.sk.

KEY WORDS: reactive oxygen species; Alzheimer disease; acetylcholinesterase; copper; Fenton reaction; disorder; heavy metal; pollution; nanoparticle.
\end{abstract}

\section{Introduction}

Copper is a chemical element with broad importance in technology including electrotechnology because of good electrical and thermal conductivity. The significance of copper can be also manifested on the fact that an archeological period Copper Age (also known as Chalcolithic respective Eneolithic from the Greek respective Latin terms for copper) is named after it. In the current time, emerging technologies and pharmacological preparations with copper nanoparticles became applicable (1-4). The global use of copper makes it an easily available metal, which can simply influence environment and health in every population. Despite copper low toxicity, some pathologies can be related to copper deposition in the body and the issue remains not fully understood (5-7).

This review focuses on the role of copper in pathological processes and copper toxicosis. The survey of actual literature is discussed in this text and identification of pathways, where copper can interfere or which can agonize or antagonize are discussed here.

Faculty of Military Health Sciences, University of Defense, Hradec Kralove, Czech Republic

Address for correspondence: M. Pohanka, MD, Faculty of Military Health Sciences, University of Defense, Trebesska 1575, CZ-500 01 Hradec Kralove, Czech Republic

Acknowledgements: A long-term organization development plan "Medical Aspects of Weapons of Mass Destruction" and Specific research funds (Faculty of Military Health Sciences, University of Defense, Czech Republic) is gratefully acknowledged.

\section{Role of copper as a biogenic metal}

Copper occurs in the environment in low concentrations. In the lithosphere, copper can be found in copper ores, but deposits containing copper are also common. For instance, copper is presented in typical European soils in the concentration between 16 and $58 \mathrm{mg} / \mathrm{kg}$ of dry material (8). People acquire copper from water and food and both of them are necessary for adults (9). Newborns have copper intake regulated as the copper is presented not free, but bound on milk proteins (10). In the body, ceruloplasmin is the main transport protein with a high storage capability, six atoms of copper per one protein, but it can be bound on the other plasmatic proteins including albumin $(11,12)$.

In metabolism, a large group of enzymes have copper as cofactor, it can be, however, involved in electron transport proteins beside the enzymes. There are four basic groups of proteins with bound copper. Group I contains single copper ion in tetrahedral stack of sulfur and nitrogen atoms, Group II contains a single copper ion in a planar arrangement, Group III contains two copper ions and the last group IV has more copper stacked in the active site (13). Because copper can change oxidative status from I+ to II + and back (the oxidative status III+ is uncommon in metabolism), it is an ideal cofactor for oxidoreductases. The enzymes from the group of oxidoreductases: $\mathrm{Cu}-\mathrm{Zn}$ superoxide dismutase catalyzing dismutation of superoxide to oxide or hydrogen peroxide (14, $15)$, nitrite reductase catalyzing reduction of nitrite to nitric oxide $(16,17), \mathrm{Cu}$ containing amine oxidase catalyzes oxidative deamination of primary amines to aldehydes with the contemporary release of hydrogen peroxide and ammonia (18-21), mitochondrial cytochrome c oxidase (complex IV) as a part of oxidative 


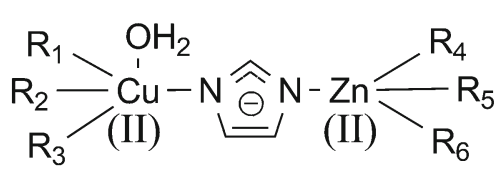

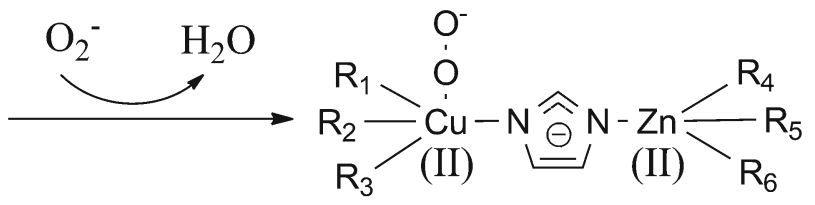

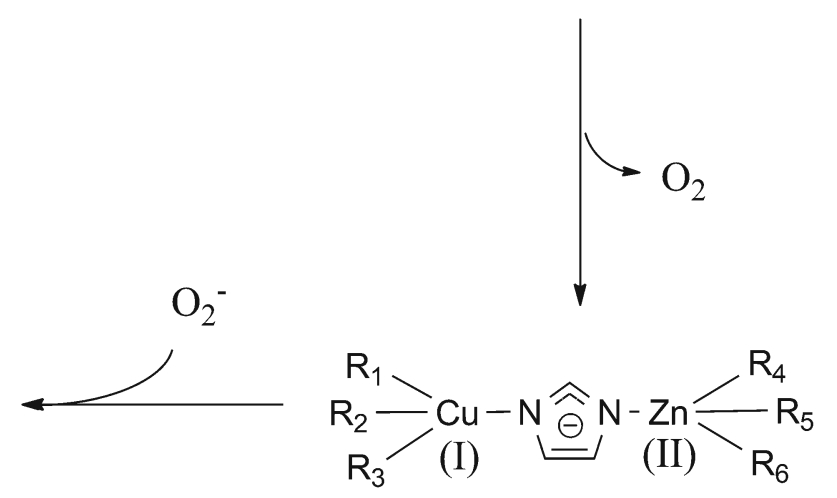

Fig. 1. Principle of $\mathrm{Cu}-\mathrm{Zn}$ superoxide dismutase catalyzed reaction with simple depiction of the active site of the enzyme function, amino acids binding zinc and copper are indicated as $\mathbf{R}_{1}-\mathbf{R}_{6}$.

phosphorylation $(22,23)$, tyrosinase responsible for oxidation of aromatic structures like neurotransmitter dopamine and amino acid tyrosine to quinones (24) and bilirubin oxidase involved in the oxidative conversion of bilirubin to biliverdin $(25,26)$ can be mentioned as the most meaningful one. Principle of $\mathrm{Cu}-\mathrm{Zn}$ superoxide dismutase catalyzed reaction with indicated oxidative states of copper is given in Figure 1. There are also copper containing enzymes known only from bacterial, fungal or plant kingdoms. Quercetin 2, 3-dioxygenase (27), laccase (28) and galactose oxidase (29) can be exampled.

Apart from enzymes, copper is a vital part of proteins responsible for electron transfer in basal metabolic processes. Plastocyanin, a metalloprotein transmitting electrons from cytochrome $f$ to cytochrome $\mathrm{b}_{6} \mathrm{f}$, is a component of light-dependent processes of photosynthesis (30). Similar transfer function has bacterial protein azurin transmitting electrons to cytochromes (31) and bacterial amicyanin (32). Copper is also a part of another significant proteins like dopamine- $\beta$-hydroxylase and lysyl oxidase. Other proteins like metallothionein, prion protein and $\beta$-amyloid precursor protein exert a high affinity towards copper and can contain copper bound in their structure though copper is not necessary for their biological function and they can be involved in the copper distribution. Prion, for instance, protects cells from copper toxicity (33). High affinity copper uptake protein is another significant macromolecule with a high affinity towards copper. It is responsible for copper intake into cells as it takes copper from proteins transporting copper through blood system. In the cells, copper is transported by copper metallochaperone protein ATOX (abbreviation from former name antioxidant protein). The exampled proteins binding copper are surveyed in the Table 1.

\section{Toxicity data}

Copper is a relatively low toxic metal, whose effect on the organism can differ in the dependence on individual conditions and especially on the individual level of proteins responsible for

Tab. 1. Exampled proteins with bound copper.

\begin{tabular}{|c|c|c|c|}
\hline Protein & Role of the protein & Role of copper & References \\
\hline ceruloplasmin & transport protein for copper, one protein carries six copper ions & transported material & 11,12 \\
\hline $\mathrm{Cu}-\mathrm{Zn}$ superoxide dismutase & it catalyzes dismutation of superoxide to oxide or hydrogen peroxide & cofactor & 14,15 \\
\hline nitrite reductase & it catalyzes reduction of nitrite to nitric oxide & cofactor & 16,17 \\
\hline amine oxidase ( $\mathrm{Cu}$ containing) & $\begin{array}{l}\text { it catalyzes oxidative deamination of primary amines to aldehydes } \\
\text { with the contemporary release of hydrogen peroxide and ammonia }\end{array}$ & cofactor & 18 \\
\hline tyrosinase & $\begin{array}{l}\text { it oxidizes aromatic structures like neurotransmitter dopamine and } \\
\text { amino acid tyrosine to quinones }\end{array}$ & cofactor & 24 \\
\hline bilirubin oxidase & it oxidizes bilirubin to biliverdin & cofactor & 25,26 \\
\hline cytochrome c oxidase & oxidative phosphorylation & cofactor & 22,23 \\
\hline plastocyanin & $\begin{array}{l}\text { it transmits electrons from cytochrome } \mathrm{f} \text { to cytochrome b6f in } \\
\text { the light-dependent processes of photosynthesis }\end{array}$ & $\begin{array}{l}\text { metal responsible for } \\
\text { electron transfer }\end{array}$ & 30 \\
\hline
\end{tabular}


<smiles>CCC(C)C(N)C(C)(C)C(N)C(=O)O</smiles>

Fig. 2. Chelating agents for therapy of poisoning by copper.

storing of copper like the aforementioned ceruloplasmin. Copper ions are toxic for small water organisms, when copper occurs as a pollutant. In the study devoted to sturgeon (Acipenser trasmontanus), Vardy and coworkers reported $\mathrm{LC}_{20}$ (water concentration causing $20 \%$ mortality) equal to $5.5 \mu \mathrm{g} / \mathrm{l}$, which was quite close to the $\mathrm{LC}_{20}$ of highly toxic cadmium - $1.5 \mu \mathrm{g} / \mathrm{l}$ (34). In another study on sturgeon (Acipenser trasmontanus), median lethal concentration $\left(\mathrm{LC}_{50}\right) 9-25 \mu \mathrm{g} / 1$ for copper was determined (35). The maximal allowable safe concentration of copper $13-18 \mu \mathrm{g} / \mathrm{l}$ for the barramundi fish (Lates calcarifer) living in brackish water was reported (36).

Humans are quite resistant to copper and acute toxicity manifestation appears at quite high doses. By taste, people sense the presence of copper in water, when it reaches $2.6 \mathrm{mg} / \mathrm{l}$ (37). In mineral water, copper level exceeding approximately $3.5 \mathrm{mg} / 1$ is noticeable by savor (37). When copper is taken with water by adults in an amount $200 \mathrm{ml}$, there was no observed adverse effect level (NOAEL) respective the lowest observed adverse effect level (LOAEL) was 6 respective $8 \mathrm{mg} / 1$ responding to total copper intake 0.8 respective $1.2 \mathrm{mg}$ (38). Similar concentrations were reached in another study where NOAEL equal to $2 \mathrm{mg} / \mathrm{l}$ was reached and LOAEL was equal to $4 \mathrm{mg} / \mathrm{l}$ for drinking water when drunk by adults in an amount $200 \mathrm{ml}$ (39). Nausea followed by vomiting were the first reported symptoms for LOAEL reaching and abdominal pain as well as diarrhea were the further manifestations of poisoning (40). The 5-HT3 and 5-HT4 receptors appears to be responsible for the manifestation of the first symptoms like vomiting $(41,42)$.

Serious poisoning by copper is quite rare. When it occurs, it leads to multi organ failure. Intravascular hemolysis, liver and renal failure are the major consequences. Median lethal dose $\left(\mathrm{LD}_{50}\right)$ for copper (II) sulphate is approximately $300 \mathrm{mg} / \mathrm{kg}$ for rats and peroral administration (43). In a case report, accidental poisoning of a 33 year old women by copper sulphate was reported (44). The women complained of overall weakness, but she was conscious and suffered from no pain. She exerted low body temperature $\left(33.2^{\circ} \mathrm{C}\right)$, had sinus tachycardia, elevated serum methemoglobin, creatinine and serous blood acidosis ( $\mathrm{pH}$ 7.1). Impairment in liver and renal function with hemolysis were proved. Copper levels in the blood reached $19.9 \mu \mathrm{mol} / 1$, when she was taken into hospital. Poisoning by copper can be treated by chelating agents and the common extracorporeal methods. Dimercaprol, penicillamine (Fig. 2) as the chelating agents and hemoperfusion and hemodiafiltration as the common extracorporeal methods could be mentioned as relevant for the therapy purposes $(45,46)$. Toxicity data for copper are summarized in Table 2.

\section{Wilson and Menkes disease as genetically determined disor- ders related to copper}

There exist genetically determined disorders related to copper. Wilson disease can be mentioned as the most relevant with an approximate frequency 0.5 up to 5 cases per 100, 000 inhabitants with a high incidence in certain regions like Costa Rica (47). In Europe, prevalence of Wilson disease is between 1.2 and 2 cases per 100, 000 inhabitants (48). The disease is caused by a mutation in ATP7B gene on chromosome 13 containing genetic information for enzyme P-type ATPase (49). Under normal conditions, the Ptype ATPase is responsible for transport of copper from liver to bile $(49,50)$. It should be written that various mutations occur in the patients suffering from Wilson disease so different patients can have different mutation resulting in P-type ATPase impairment (51, 52). Regardless of mutation type in the ATP7B gene, the impaired P-type ATPase leads to copper accumulation in multiple organs with fatal consequences if untreated (53). Typically liver, but also brain, nerves and other tissues are targeted by copper deposition and copper toxicity is manifested through failure of these organs (54-56). Formation of Kayser-Fleischer rings, copper deposits in the cornea, are visual manifestations of Wilson disease in its developed phase and the deposits are clearly visible in the eyes of patients through a detailed examination using slit lamps $(57,58)$. Because the Wilson disease is typical autosomal genetically de-

Tab. 2. Copper toxicity data.

\begin{tabular}{llcc}
\hline Parameter & Conditions & Value & References \\
\hline $\mathrm{LC}_{50}$ & sturgeon (Acipenser trasmontanus), exposure from ambient water & $9-25 \mu \mathrm{g} / \mathrm{l}$ & 35 \\
\hline $\begin{array}{l}\text { the maximal allowable safe } \\
\text { concentration }\end{array}$ & barramundi fish (Lates calcarifer) & $13-18 \mu \mathrm{g} / \mathrm{l}$ & 36 \\
\hline Recognizing of taste in water & water containing Cu drank by volunteers & $2.6 \mathrm{mg} / \mathrm{l}$ & 37 \\
\hline NOAEL & water containing Cu drank by volunteers in an amount $200 \mathrm{ml}$ & $\begin{array}{c}6 \mathrm{mg} / \mathrm{l} \text { (total dose per } \\
\text { volunteer } 0.8 \mathrm{mg} \text { ) }\end{array}$ & 38 \\
\hline LOAEL & $\begin{array}{l}\text { water containing Cu drank by volunteers in an amount } 200 \mathrm{ml}, \text { nausea } \\
\text { and vomiting taken for the symptoms of intoxication }\end{array}$ & $\begin{array}{c}8 \mathrm{mg} / \mathrm{l} \text { (total dose per } \\
\text { volunteer } 1.2 \mathrm{mg} \text { ) }\end{array}$ & 38 \\
\hline $\mathrm{LD}_{50}$ & copper sulfate (II) perorally administered to rats & $300 \mathrm{mg} / \mathrm{kg}$ & 43 \\
\hline Blood concentration & case report, hemolysis, liver and renal failure occurred & $19.9 \mu \mathrm{mol} / 1$ & 44 \\
\hline
\end{tabular}


termined disorder, the manifestation and progression depends on the fact whether the mutations are homozygous or heterozygous (59). Pathologies involved in the Wilson disease clearly depicts how a health organism is protected by chelating proteins and how copper is toxic, when the protecting pathways fail. Like the other heavy metals, pathways for elimination from body are slow without specific transporters and accumulation followed by deposition is endangering homeostasis.

Menkes disease is another genetically determined disorder. In contrast to the Wilson disease, where mutation is located on autosome, the Menkes disease is related to X chromosome so the disease is manifested in men with mutation in their chromosome or in a woman in X-linked recessive inheritance mode. In the Menkes disease, gene ATP7A for copper-transporting P-type ATPase is mutated $(60,61)$. Various mutations can occur in the ATP7A gene resulting in the lack of the coded P-type ATPase in the Trans-Golgi Network, which is natural site, where it is active and the lack of the copper concentration in the Golgi apparatus follows (62). The ATP7A P-type ATPase is expressed in other organs than the ATP7B type known from Wilson disease so the diseases are manifested in distant manner. In the Menkes disease, copper is deficient in blood, liver, and brain while excess of copper is deposited in the other body parts like intestinal tissue (63, 64). Menkes disease cannot be entitled as copper toxicosis, but it is rather a combination of the contemporary deficiency and overdosing and the deficiency, respective overdosing, is site specific. Because different organs are involved in the copper deposition in Wilson and Menkes diseases, different drugs are used for therapy purposes. Copper-histidine, thiocarbamate, nitrilotriacetate and lipoic acids are used in the case of Menkes disease, and hydrophilic chelators trientine, D-penicillamine and dimercaptosuccinate serve for the Wilson disease therapy $(63,65)$. Occipital horn syndrome is a disease close to the Menkes disease. The occipital horn syndrome is also related to the ATP7A gene for P-type ATPase like known in the Menkes disease, but the activity of the enzyme is partially kept hence the manifestation is not so serious (66-69). Survey of genetically determined disorders, where copper plays a relevant role is summarized in the Table 3. Other pathologies related to copper that are less frequent exists as well. Idiopathic copper toxicosis (70), Indian childhood cirrhosis (71) and Tyrolean infantile cirrhosis (72-74) can be exampled.

\section{Alzheimer disease and the other neurodegenerations}

Alzheimer disease is a neurodegenerative disorder with an unknown etiology. The disease is a progressive pathology related to nervous system, where amyloid plaques and cellular tangles of tau protein are formed as the major molecular hallmarks (75-77). In the beginning of Alzheimer disease discovery, aluminum was considered the causative agent and the fact was supported by finding of aluminum traces in damaged tissues (78-80). In the later research, aluminum was taken for improbable cause of the disease though some research is still ongoing (81). Currently, aluminum deposition in the brain is considered a consequence rather than a cause of the disease (82). Though aluminum role in Alzheimer disease brought a huge attention since the beginning of twentieth century, when the disease was discovered, other metals are also considered as contributors to pathologies related to the disease. Involvement of other metals like mercury, zinc, cadmium and lead in Alzheimer disease is discussed in the current literature (83-86). Copper belongs between the researched metals and some relations between Alzheimer disease and copper were found and binding sites for copper were identified in amyloid plaques (87).

Copper has a high affinity to amyloid $\beta$ peptide with length of 42 amino acids, which is a precursor of amyloid plaque; however, it also initialize aggregation of the peptides and copper cations can be considered effective catalyzers of the aggregation (88). In the presence of hydrogen peroxide and nitrite, copper (II) is able to cause nitration of the amyloid $\beta$ peptide with length 42 amino acids (88). Comparing to iron and aluminum ions producing fibrillar amyloid oligomers with size up to $30 \mathrm{~nm}$, copper ions catalyze formation of larger insoluble plaques (89). Another possible negative role of copper is mediated thorough blocking of amyloid $\beta$ peptide degradation. Under normal conditions, zinc metalloprotease known as insulin-degrading enzyme is able to split the amyloid $\beta$ peptide with length of 42 amino acids, but copper in the oxidative states I and II and silver ions act as inhibitors of the enzyme (90). Copper (I) was identified as an irreversible inhibitor of the insulin-degrading enzyme (91). Though the role of copper in amyloid plaques formation can appear as a plausible fact regarding to the aforementioned studies, the final conclusions appears to be far from such statement. While molecular mechanisms can correspond with symptomatic manifestations known from the

Tab. 3. Genetically determined disorders related to copper.

\begin{tabular}{llll}
\hline Disease & Reason & copper in the disease & therapy \\
\hline Wilson disease & $\begin{array}{l}\text { mutation in ATP7B gene } \\
\text { for P-type ATPase }\end{array}$ & $\begin{array}{l}\text { impaired P-type ATPase leads to copper } \\
\text { accumulation in multiple organs including } \\
\text { liver and brain and nerves }\end{array}$ & $\begin{array}{l}\text { copper-histidine, thiocarbamate, } \\
\text { nitrilotriacetate and lipoic acids }\end{array}$ \\
\hline Menkes disease & $\begin{array}{l}\text { mutation in ATP7A gene } \\
\text { for P-type ATPase }\end{array}$ & $\begin{array}{l}\text { impaired P-type ATPase leads to copper } \\
\text { accumulation in various organs, but copper } \\
\text { is insufficient in liver and brain }\end{array}$ & $\begin{array}{l}\text { trientine, D-penicillamine and } \\
\text { dimercaptosuccinate }\end{array}$ \\
\hline $\begin{array}{l}\text { occipital horn } \\
\text { syndrome }\end{array}$ & $\begin{array}{l}\text { mutation in ATP7A gene } \\
\text { for P-type ATPase, partial } \\
\text { activity remains }\end{array}$ & $\begin{array}{l}\text { impaired P-type ATPase leads to copper } \\
\text { accumulation in various organs, but } \\
\text { copper is insufficient in liver and brain, the } \\
\text { manifestation is milder, when compared to } \\
\text { the Menkes disease }\end{array}$ & like therapy of Menkes disease \\
\hline
\end{tabular}


Tab. 4. Copper role in neurodegenerative disorders.

\begin{tabular}{ll}
\hline Disorder & Effect of copper \\
\hline Alzheimer disease & supporting of amyloid $\beta$ peptide aggregation to amyloid plaques \\
\hline Alzheimer disease & nitration of the amyloid $\beta$ peptide in presence of hydrogen peroxide, nitrite and copper (II) \\
\hline $\begin{array}{l}\text { Alzheimer disease } \\
\text { Parkinson disease }\end{array}$ & $\begin{array}{l}\text { copper inhibits insulin-degrading enzyme, the enzyme is then unable to hydrolyze amyloid } \beta \\
\text { peptide and protect from amyloid plaques formation }\end{array}$ \\
\hline Parkinson disease & number of copper ions bound on one molecule of ceruloplasmin is reduced \\
\hline $\begin{array}{l}\text { Dementia with Lewy bodies, }, \\
\text { Parkinson disease }\end{array}$ & $\begin{array}{l}\text { copper induces } \alpha \text { synuclein aggregation, metallothionein plays a protective role for the } \alpha \\
\text { from Parkinson disease }\end{array}$ \\
\hline
\end{tabular}

neurodegenerative disorders, the mechanisms were not proved in clinical studies and the role of copper can be overestimated or even underestimated in the real situations.

Parkinson disease is another pathology, where copper can be a significant factor though detailed experiments on the issue has not been done yet. The both Alzheimer and Parkinson diseases have increased probability of onset in elderly people. Tremor and movement impairment are the major visual manifestations of Parkinson disease (92). On the molecular level, degradation of protein $\alpha$ synuclein leading to formation of Lewy bodies predominantly in the pars compacta of substantia nigra is the main hallmark of the disease (93-95). The formation of Lewy bodies is not privileged to Parkinson disease, but a group of disorders known as dementia with Lewy bodies is currently distinguished $(96,97)$. The aggregation of Lewy bodies from $\alpha$ synuclein is not fully understood and probably abnormal degradation processes of the $\alpha$ synuclein, misfolding, acting of other proteins and enzymes, redox processes and phosphorylation take place in the pathology (98-100). Unfortunately, it is not even clear whether the formation of Lewy bodies is a cause or consequence of the disease and even opinions that it is a process protecting cells from another molecular damage are logical (101).

The role of metals in pathologies based on Lewy bodies was studied and significant indications that the metals can be involved in these diseases was revealed. In the work by Gorell and coworkers, association of Parkinson disease with copper or manganese and combinations of mixtures containing lead, iron and copper were proved $(102,103)$. The potentiation between copper and iron in Parkinson disease patients was proved in cerebrospinal fluid as well (104). Another study reported that number of copper ions bound on one molecule of ceruloplasmin was reduced in patients suffering from Parkinson disease (105). Using a model comprising laboratory rats, symptoms of Parkinson disease and damaging of the pars compacta of substantia nigra was initiated by administered copper (106). Copper was also proved an effective catalyzer able to initiate $\alpha$ synuclein aggregation and protective effect of metallothionein was described in the same study (107). The authors inferred that this effect is significant for the development of dementia with Lewy bodies and Parkinson disease and they proved a reduction of the copper effect on $\alpha$ synuclein, when metallothionein is up regulated. In the recent search on 50 patients and 50 health volunteers, decreased blood total copper level and ceruloplasmin levels were proved in patients, which suffered from Parkinson disease, when compared to the controls (108). Comparing the aforementioned studies, Kim and coworkers found another results in their study performed on 325 patients suffered from Parkinson disease and 304 controls (109). They concluded their work by a statement that higher copper levels are proportional to a reduced risk of Parkinson disease and increased copper level is beneficial for a higher score in mini-mental state examination test. It is obvious that the inconsequent findings on the role copper in neurodegenerations should be explained by the next experiments and more work on the issue is necessary prior to make the final conclusion. The role of copper is also questionable, because the genetically determined disorders related to copper (Menkes disease, Wilson disease) are not manifested by same signs like Alzheimer or Parkinson disease. It appears that copper is or at least can be involved in the neurodegenerative disorders, but the real mechanism of copper effect is based on more factors and there is probably no simple proportionality and the effect is probably in a close connection to other processes, level of particular proteins and metabolic pathways. The role of copper in neurodegenerative disorders is summarized in Table 4.

The implication of copper mechanism in neurodegenerative disorders can be based on chemical redox reactions producing radical forms of oxygen. A common mechanism getting arise of hydroxy radical is called Fenton reaction named in honor to British scientist Henry John Horstman Fenton. The reaction is consisting of oxidation of a metal in presence of hydrogen peroxide resulting in arising of hydroxyl anion and hydroxyl radical. Copper (I

$$
\mathrm{Cu}(\mathrm{I})+\mathrm{H}_{2} \mathrm{O}_{2} \longrightarrow \mathrm{Cu}(\mathrm{II})+\mathrm{OH}^{-}+\mathrm{OH} \cdots-\begin{aligned}
& \text { redox reactions } \\
& \text { cytotoxic effect }
\end{aligned}
$$

Fig. 3. Fenton reaction for copper and indication of further effects initiated by hydroxyl radical. 
Tab. 5. Pathways interfered by copper.

\begin{tabular}{|c|c|c|}
\hline Pathway or biomolecule & Copper effect & References \\
\hline acetylcholinesterase & non-competitive inhibition & 126 \\
\hline proteases, esterases, lipases, glucosidases & inhibition & 127 \\
\hline succinate dehydrogenase & inhibition & 128 \\
\hline carbonic anhydrase & reduction of activity & 128 \\
\hline innate immunity & $\begin{array}{l}\text { increased nuclear factor } \kappa \mathrm{B} \text {, cyclooxygenase } 2 \text {, inducible nitric oxide synthase, } \\
\text { prostaglandin E synthase }\end{array}$ & 129 \\
\hline
\end{tabular}

oxidized to II) and iron (II oxidized to III) ions are typical metals, which are able to initiate the Fenton reaction, various metallic oxides and bimetallic oxides are also highly active (110-112). The metal is further reduced by mechanisms like Haber-Weiss reaction in the presence of superoxide anion and hydrogen peroxide and the Fenton reaction can be initiated again (113-115). The arisen hydroxyl radical is a highly reactive compound able to initiate radical reaction and it also acts as a cytotoxin $(116,117)$. The Fenton reaction can be just the pathway associated with the neurodegenerative disorders. Just the hydroxyl radical can be the molecule initiating various pathologies by uncontrollable damaging of macromolecules and initiating processed finally leading up to the mentioned disorders like Alzheimer disease $(118,119)$. The Fenton reaction for copper is expressed in Figure 3.

\section{Various pathways and processes}

As a catalytically active metal, copper can interfere or influence many metabolic, regulatory and functional pathways in the body. The impact is not exclusive for higher organisms because the effects are also manifested on microorganisms $(120,121)$. Preparations containing copper have use in the agriculture as fungicides since copper can harm mold and spraying of plants like fruit trees and vine is an effective manner how to protect them. On the other hand, copper can harm the organisms living in the proximity of protected plants (122-125). A non-competitive inhibition of enzyme acetylcholinesterase with inhibitory equilibrium constant $\mathrm{K}_{\mathrm{i}}$ equal to $0.781 \mathrm{mmol} / 1$ (126), inhibition of proteases, esterases, lipases, glucosidases (127), reduction of carbonic anhydrase activity and inhibition of succinate dehydrogenase activity (128) were identified as possible pathways, where copper can act. Survey of the pathways is shown as Table 5 .

Immunity is another function that can be influenced by copper. Though copper alone is not recognized as an antigen and does not initialize immunity in a true sense of the world, it can modify response of immune system to an antigen. In the study by Liu and co-workers, concurrent application of arsenic and copper was examined on a chicken animal model (129). The authors revealed an intense pro-inflammatory and stress response as nuclear factor $\kappa \mathrm{B}$, cyclooxygenase 2 , inducible nitric oxide synthase, prostaglandin $\mathrm{E}$ synthase were significantly increased. The effect of copper on immunity cannot be, however, concluded by a simple statement that only overdosing by copper has a significant impact on immunity because limited intake is also relevant. Cholewinska and coworkers recognized that diet with limited content of copper caused a reduction of interleukin 6 and immunoglobulin $\mathrm{E}$ in plasma of rats (130). The previous experiments can be concluded that copper is a biogenic metal hence its recommended intake should be kept otherwise innate and even adaptive immunity can fail and organism is not able to produce cytokines in demanded amount. On the other hand, an excessive amount of copper can support inflammatory processes, which was proved for instance, when people were exposed to copper from welding fumes $(131,132)$.

Copper is not considered as a carcinogenic substance; on the other hand, the role of copper in progression of some types of cancer have been proposed. The supporting effect of copper to cancer is based on the fact that copper is necessary for angiogenesis and increased angiogenesis is necessary for formation of a tumor. Copper is not of course a cause of cancer, but blocking of copper acquire can slow down formation of the new blood vessels and cancer progression became suppressed $(133,134)$. Comparing to the research indicating that copper can be somewhat involved in a tumor progression, some studies contrary proved a protection to cancer by copper, which was mediated by supporting of enzymes such as: superoxide dismutase and others, where copper act as a cofactor (135-137).

\section{Copper nanoparticles}

Production of copper nanoparticles is an emerging technology process and many studies on the issue appeared in the recent time (138-145). Copper is a relatively cheap material with good electrical and thermal conductivity on one side and good long-term stability resistance to oxidation on the other. The same can be told for copper (II) oxide, which is a material suitable for nanoparticles construction and exerting good chemical and electrochemical properties as well. Copper or copper oxide containing particles exert specific optical parameters and they can be used in photocatalyst synthesis (146). The copper nanoparticles can be pure, but production of composites and mixed content structures provide better functional parameters. Advanced production techniques like thermal sintering (147), laser assisted sintering (148), electrodeposition (149), biotechnological processes (150), standard chemical synthesis $(151,152)$ and click chemistry $(151)$ are options for copper nanoparticles preparation and production. Copper nanoparticles have broad application use due to their physical 
and chemical properties. Antimicrobial applications $(153,154)$ or other regulation of microorganism growth (155), use of unique optical properties like fluorescence (156) including application to improving of quantum dots properties (157) and sensor systems, where the copper nanoparticles can carry another functional part like biomolecules (158) or serve as pseudoenzymes (159-161) are examples of specific use.

When the nanoparticles appeared, toxicity of them became recognized as an important issue because they can cause pollution of environment and occupational risks. Because some applications are expected to be in medicine, the toxicity is also a serious factor necessary to be known before a planned use. Unfortunately, data about copper nanoparticles are limited and their toxicity has not been completely studied yet (162). The copper nanoparticles effect on an organism can be inferred from the currently available studies focused on particular pathways and general toxicity scaling. Chen and co-workers studied copper nanoparticles with a size $23.5 \mathrm{~nm}$ and compared it with micro particles sized $17 \mu \mathrm{m}$ and solved cupric ions (163). They discovered that $\mathrm{LD}_{50}$ value for mice exposed via oral gavage was equal to $413 \mathrm{mg} / \mathrm{kg}$ for the nanoparticles, more than $5000 \mathrm{mg} / \mathrm{kg}$ for the microparticles and about $110 \mathrm{mg} / \mathrm{kg}$ for cupric ions. The results showed that particles are less toxic than solved ions and the toxicity decrease with an increased size. On the other hand, the conclusions were done for oral application and it cannot be generalized for other routes of particles application. In a paper by Torres-Duarte and coworkers, there was a described effect of copper oxide nanoparticles on Mediterranean mussels (Mytilus galloprovincialis), when the mussels were contemporary infected with pathogenic bacteria (164). The authors exposed the mussels to concentration of copper nanoparticles in a range from 100 to 450 $\mu \mathrm{g} / \mathrm{l}$ and let them expose to pathogenic bacterium Vibrio tubiashii. In the study, the mussels exerted an increased sensitivity to the infection when copper nanoparticles presented, similar effect was observed when copper sulphate was added to water batch with the mussels. The authors concluded their work by finding that cellular toxicity of copper nanoparticles and increasing of reactive oxygen nanoparticles are responsible for the effect. Toxicity of copper oxide nanoparticles is also manifested on plants (165). In a complex experiment, Rajput and co-workers described the impact of copper oxide nanoparticles on spring barley (Hordeum sativum) as a representative staple food crop (166). The barley grown in the presence of copper nanoparticles had a reduced size, changes in morphology and depressed yield of photosynthesis. Especially roots were highly reduced and germination rate was also significantly lower in the plant exposed to copper nanoparticles, when compared to the controls.

Nanoparticles become a relevant noxious substances and their release from electronic devices and presence in the environment causes a potential risk for humans and lungs are one of the most endangered organs (167). In the recent experiment, toxicity of copper oxide nanoparticles intranasally administered was examined on 57BL/6 mice (168). The used copper nanoparticles induced pulmonary inflammation resulting in fibrosis. The mechanism of pulmonary toxicity was not fully responded, but increased forms of reactive oxygen species and started oxidative stress was taken for the main cause copper nanoparticles toxicity in this experiment. The effect copper nanoparticles and healing of the impact can be also learned by Gosens and co-workers (169). The authors applied copper oxide nanoparticles to rats intranasally for five days and the effect of copper nanoparticles was examined one day and 22 days after the exposure ending. One day after the exposure ending, lung inflammation, alveolitis, bronchiolitis, vacuolation, damage of epithelium and damaging of olfactory epithelium was observed. After the 22 days, the most damaged tissues were healed though limited inflammation was still observable in the examined tissues from animals receiving the upper dose of copper oxide nanoparticles.

The toxicity of copper nanoparticles is not, however, based only on lung damaging. After intake, the particles became circulating and can be deposited in various organs and tissues. In an

Tab. 6. Copper nanoparticles toxicity effect.

\begin{tabular}{|c|c|c|c|c|}
\hline $\begin{array}{l}\text { Material of copper } \\
\text { nanoparticle }\end{array}$ & Tested organism & $\begin{array}{l}\text { Route of } \\
\text { application }\end{array}$ & Observed effect of copper nanoparticles & References \\
\hline copper oxide & $\begin{array}{l}\text { mussels (Mytilus } \\
\text { galloprovincialis) }\end{array}$ & $\begin{array}{l}\text { exposure from } \\
\text { ambient water }\end{array}$ & $\begin{array}{l}\text { increased susceptibility of mussels to infection by Vibrio tubiashii, } \\
\text { the copper nanoparticles probably caused the sensitivity by } \\
\text { generation of reactive oxygen species and cellular toxicity }\end{array}$ & 164 \\
\hline copper oxide & $\begin{array}{l}\text { spring barley } \\
\text { (Hordeum sativum) }\end{array}$ & $\begin{array}{l}\text { exposure } \\
\text { from soil }\end{array}$ & reduced size, changes in morphology, depression of photosynthesis & 166 \\
\hline copper oxide & 57BL/6 mice & $\begin{array}{l}\text { intranasal } \\
\text { application }\end{array}$ & $\begin{array}{l}\text { pulmonary inflammation, fibrosis, reactive oxygen species } \\
\text { generation }\end{array}$ & 168 \\
\hline copper oxide & rats & $\begin{array}{l}\text { intranasal } \\
\text { application }\end{array}$ & $\begin{array}{l}\text { lung inflammation, alveolitis, bronchiolitis, vacuolation, damage } \\
\text { of epithelium and damaging of olfactory epithelium one day after } \\
\text { the nanoparticles application; limited pathological consequences } \\
22 \text { days after exposure }\end{array}$ & 169 \\
\hline copper & female rats & $\begin{array}{l}\text { intraperitoneal } \\
\text { application }\end{array}$ & $\begin{array}{l}\text { uterus weight reduction, inflammatory cells infiltration, oxidative } \\
\text { stress development, apoptotic processes }\end{array}$ & 170 \\
\hline copper oxide & rats & oral gavage & $\begin{array}{l}\text { bone marrow, stomach and liver damage observable by } \\
\text { histopathology }\end{array}$ & 171 \\
\hline $\begin{array}{l}\text { copper carbonate } \\
\mathrm{Cu}_{2} \mathrm{CO}_{3}(\mathrm{OH})_{2}\end{array}$ & rats & oral gavage & $\begin{array}{l}\text { stomach, liver, intestines, spleen, thymus, kidneys, and bone } \\
\text { marrow damage observable by histopathology }\end{array}$ & 171 \\
\hline
\end{tabular}


experiment by $\mathrm{Hu}$ and co-workers, intraperitoneally applied copper nanoparticles for fourteen days have an impact on uterus of rats (170). The female rats received approximately from 3 to 13 $\mathrm{mg} / \mathrm{kg}$ of copper nanoparticles per a day and they were euthanized after two weeks. After examination, uteruses were reduced in their weight and infiltration of inflammatory cells was augmented, there were also reported increased oxidative stress markers like malondialdehyde, superoxide dismutase, cell death activation was also initiated by expression of caspases 3, 8, and 9, BCL2-associated $\mathrm{X}$, apoptosis regulator Bax, apoptotic peptidase activating factor 1 , and other 622 genes were upregulated as well. The findings can be interpreted that inflammation and oxidative stress started in uteruses of rats, when exposed to copper nanoparticles. Peroral toxicity of copper nanoparticles can be learned from the work by De Jong and co-workers (171). The researchers tested toxicity of copper oxide and copper carbonate $\mathrm{Cu}_{2} \mathrm{CO}_{3}(\mathrm{OH})_{2}$ nanoparticles in rats receiving the nanoparticles by oral gavage for consecutive five days. The impact of nanoparticles was evaluated from the sixth up to 26th day after experiment starting and histopathological examination of organs followed. While copper oxide nanoparticles caused an observable alteration in bone marrow, stomach and liver, copper carbonate nanoparticles had effect on stomach, liver, intestines, spleen, thymus, kidneys, and bone marrow. Typically, ulceration, degeneration and inflammation were the main manifestations. The unequal effect of copper oxide and copper carbonate effect on the model organism is quite interesting and it point at the fact that the chemical composition should be further tested. Size and shape would be also crucial parameters, which should be further researched. The afore described effects caused by copper nanoparticles are summarized in Table 6 .

Copper nanoparticles are an emerging technology with a broad applicability in the current economy; however, their impact on the human physiology is underestimated as can be learned from the previously quoted studies. The copper nanoparticles are more harmful than the copper itself. Though the mechanisms of copper nanoparticles toxicity have not been fully revealed yet, two major factors contributing to their toxicity can be inferred. Firstly, they act as potent oxidative catalyzers and because the nanoparticles are not catch by transport and storage proteins like the pure copper, their catalytic potency is not blocked. Secondly, elimination and metabolic processes (detoxification reactions the first, second and third phase) related to copper particles are not functional or fully effective because of their size and different physical and chemical properties, when compared to the pure copper.

\section{Conclusions}

Copper is an important biogenic element with harmful impact on an organism, when taken in recommended doses. Augmented use of copper in technology, pharmacy, agriculture and other aspects of human life make it available in doses exceeding the recommended doses. Under various conditions copper can implicate into pathologic processes from which many of them remain poorly understood. Especially connection between endogenous copper and neurodegenerative disorders is intensively and extensively studied but no complete conclusion is available. Copper nanoparticles is another issue because of the nanoparticles' high toxicity and not fully known mechanism how they act in the body. Impact of copper and copper nanoparticles on organisms should be further investigated because of the copper relevance and seriousness of the pathological processes that can be initiated by copper and copper nanoparticles.

\section{References}

1. Deka P, Borah BJ, Saikia H, Bharali P. Cu-based nanoparticles as emerging environmental catalysts. Chem Rec 2018; 17 (10): 201800055.

2. Ullah I, Khan K, Sohail M, Ullah K, Ullah A, Shaheen S. Synthesis, structural characterization and catalytic application of citrate-stabilized monometallic and bimetallic palladium@copper nanoparticles in microbial anti-activities. Int J Nanomedicine 2017; 12: 8735-8747.

3. George JM, Antony A, Mathew B. Metal oxide nanoparticles in electrochemical sensing and biosensing: A review. Mikrochim Acta 2018; 185 (7): 018-2894.

4. Khalaj M, Kamali M, Khodaparast Z, Jahanshahi A. Copper-based nanomaterials for environmental decontamination - an overview on technical and toxicological aspects. Ecotoxicol Environ Saf 2018; 148: 813-824.

5. DeForest DK, Gensemer RW, Gorsuch JW et al. Effects of copper on olfactory, behavioral, and other sublethal responses of saltwater organisms: Are estimated chronic limits using the biotic ligand model protective? Environ Toxicol Chem 2018; 37 (6): 1515-1522.

6. Bulcke F, Dringen R, Scheiber IF. Neurotoxicity of copper. Adv Neurobiol 2017; 18: 313-343.

7. Dusek P, Roos PM, Litwin T, Schneider SA, Flaten TP, Aaseth J. The neurotoxicity of iron, copper and manganese in Parkinson's and Wilson's diseases. J Trace Elem Med Biol 2015; 31: 193-203.

8. Heijerick DG, Van Sprang PA, Van Hyfte AD. Ambient copper concentrations in agricultural and natural European soils: An overview. Environ Toxicol Chem 2006; 25 (3): 858-864.

9. Tsai JW, Ju YR, Huang YH et al. Toxicokinetics of tilapia following high exposure to waterborne and dietary copper and implications for coping mechanisms. Environ Sci Pollut Res Int 2013; 20 (6): 3771-3780.

10. Puchkova LV, Babich PS, Zatulovskaia YA, Ilyechova EY, Di Sole F. Copper metabolism of newborns is adapted to milk ceruloplasmin as a nutritive source of copper: Overview of the current data. Nutrients 2018; 10 (11).

11. Myint ZW, Oo TH, Thein KZ, Tun AM, Saeed H. Copper deficiency anemia: Review article. Ann Hematol 2018; 97 (9): 1527-1534.

12. Weiss KH, Czlonkowska A, Hedera P, Ferenci P. Wtx101 - an investigational drug for the treatment of Wilson disease. Expert Opin Investig Drugs 2018; 27 (6): 561-567.

13. Cass AE, Hill HA. Copper proteins and copper enzymes. Ciba Found Symp 1980; 79: 71-91.

14. Han XM, Chen QX, Yang Q, Zeng QY, Lan T, Liu YJ. Genomewide analysis of superoxide dismutase genes in larix kaempferi. Gene 2018; 686: 29-36.

15. Campos-Shimada LB, Hideo Gilglioni E, Fernandes Garcia R, Rizato Martins-Maciel E, Luiza Ishii-Iwamoto E, Luzia Salgueiro- 
Pagadigorria C. Superoxide dismutase: A review and a modified protocol for activities measurements in rat livers. Arch Physiol Biochem 2018; 29: $1-8$.

16. Lintuluoto M, Lintuluoto JM. Intra-electron transfer induced by protonation in copper-containing nitrite reductase. Metallomics 2018; 10 (4): 565-578.

17. Chandra Maji R, Mishra S, Bhandari A, Singh R, Olmstead MM, Patra AK. A copper(ii) nitrite that exhibits change of nitrite binding mode and formation of copper(ii) nitrosyl prior to nitric oxide evolution. Inorg Chem 2018; 57 (3): 1550-1561.

18. Zhang X, Wang Q, Wu J, Wang J, Shi Y, Liu M. Crystal structure of human lysyl oxidase-like 2 (hloxl2) in a precursor state. Proc Natl Acad Sci USA 2018; 115 (15): 3828-3833.

19. Yang H, Ralle M, Wolfgang MJ et al. Copper-dependent amino oxidase 3 governs selection of metabolic fuels in adipocytes. PLoS Biol 2018; 16 (9)

20. Mills SA, Gazica KE, Tierney DL. Co(ii) is not oxidized during turnover in the copper amine oxidase from hansenula polymorpha. J Biol Inorg Chem 2018; 23 (10): 018-1624.

21. Kishishita S, Okajima T, Kim M et al. Role of copper ion in bacterial copper amine oxidase: Spectroscopic and crystallographic studies of metal-substituted enzymes. J Am Chem Soc 2003; 125 (4): 1041-1055.

22. Torrado A, Ramirez-Moncayo C, Navarro JA, Mariscal V, MolinaHeredia FP. Cytochrome c6 is the main respiratory and photosynthetic soluble electron donor in heterocysts of the cyanobacterium anabaena sp. Pcc 7120. Biochim Biophys Acta Bioenerg 2018; 7 (18): 30200-30207.

23. Vilhjalmsdottir J, Gennis RB, Brzezinski P. The electron distribution in the "activated" state of cytochrome c oxidase. Sci Rep 2018; 8 (1): 018-25779.

24. Ghani U. Carbazole and hydrazone derivatives as new competitive inhibitors of tyrosinase: Experimental clues to binuclear copper active site binding. Bioorg Chem 2018; 83: 235-241.

25. Morishita H, Kurita D, Kataoka K, Sakurai T. Study on dioxygen reduction by mutational modifications of the hydrogen bond network leading from bulk water to the trinuclear copper center in bilirubin oxidase. Biochem Biophys Res Commun 2014; 450 (1): 767-772.

26. Cracknell JA, McNamara TP, Lowe ED, Blanford CF. Bilirubin oxidase from myrothecium verrucaria: X-ray determination of the complete crystal structure and a rational surface modification for enhanced electrocatalytic o2 reduction. Dalton Trans 2011; 40 (25): 6668-6675.

27. Malkhasian AY, Howlin BJ. Docking and dft studies on ligand binding to quercetin 2, 3-dioxygenase. J Biomol Struct Dyn 2016; 34 (11): 2453-2461.

28. Patel N, Shahane S, Shivam S, Majumdar R, Mishra U. Mode of action, properties, production, and application of laccase: A review. Recent Pat Biotechnol 2018; 21 (92582): 1872208312666180821161015.

29. Vilim J, Knaus T, Mutti FG. Catalytic promiscuity of galactose oxidase: A mild synthesis of nitriles from alcohols, air, and ammonia. Angew Chem Int Ed Engl 2018; 57 (43): 14240-14244.

30. Hippmann AA, Schuback N, Moon KM et al. Contrasting effects of copper limitation on the photosynthetic apparatus in two strains of the open ocean diatom thalassiosira oceanica. PLoS One 2017; 12 (8).

31. Shen L, Zeng X, Hu H, Hu X, Yang W. Accurate quantum mechani$\mathrm{cal} /$ molecular mechanical calculations of reduction potentials in azurin variants. J Chem Theory Comput 2018; 14 (9): 4948-4957.
32. Dow BA, Sukumar N, Matos JO et al. The sole tryptophan of amicyanin enhances its thermal stability but does not influence the electronic properties of the type 1 copper site. Arch Biochem Biophys 2014; 551: 20-27.

33. Haigh CL, Brown DR. Prion protein reduces both oxidative and nonoxidative copper toxicity. J Neurochem 2006; 98 (3): 677-689.

34. Vardy DW, Tompsett AR, Sigurdson JL et al. Effects of subchronic exposure of early life stages of white sturgeon (acipenser transmontanus) to copper, cadmium, and zinc. Environ Toxicol Chem 2011; 30 (11): 2497-2505.

35. Vardy DW, Santore R, Ryan A, Giesy JP, Hecker M. Acute toxicity of copper, lead, cadmium, and zinc to early life stages of white sturgeon (acipenser transmontanus) in laboratory and columbia river water. Environ Sci Pollut Res Int 2014; 21 (13): 8176-8187.

36. Krishnani KK, Azad IS, Kailasam M et al. Acute toxicity of some heavy metals to lates calcarifer fry with a note on its histopathological manifestations. J Environ Sci Health A Tox Hazard Subst Environ Eng 2003; 38 (4): 645-655.

37. Zacarias I, Yanez CG, Araya M, Oraka C, Olivares M, Uauy R. Determination of the taste threshold of copper in water. Chem Senses 2001; 26 (1): 85-89.

38. Araya M, McGoldrick MC, Klevay LM et al. Determination of an acute no-observed-adverse-effect level (noael) for copper in water. Regul Toxicol Pharmacol 2001; 34 (2): 137-145.

39. Olivares M, Araya M, Pizarro F, Uauy R. Nausea threshold in apparently healthy individuals who drink fluids containing graded concentrations of copper. Regul Toxicol Pharmacol 2001; 33 (3): 271-275.

40. Araya M, Chen B, Klevay LM et al. Confirmation of an acute noobserved-adverse-effect and low-observed-adverse-effect level for copper in bottled drinking water in a multi-site international study. Regul Toxicol Pharmacol 2003; 38 (3): 389-399.

41. Fukui H, Yamamoto M, Sasaki S, Sato S. Possible involvement of peripheral 5-ht4 receptors in copper sulfate-induced vomiting in dogs. Eur J Pharmacol 1994; 257 (1-2): 47-52.

42. Fukui H, Yamamoto M, Sasaki S, Sato S. Involvement of 5-ht3 receptors and vagal afferents in copper sulfate- and cisplatin-induced emesis in monkeys. Eur J Pharmacol 1993; 249 (1): 13-18.

43. World-Health-Organization. 200: Copper. Environmental Health Criteria 1998; 1998: 101

44. Sinkovic A, Strdin A, Svensek F. Severe acute copper sulphate poisoning: A case report. Arh Hig Rada Toksikol 2008; 59 (1): 31-35.

45. Takeda T, Yukioka T, Shimazaki S. Cupric sulfate intoxication with rhabdomyolysis, treated with chelating agents and blood purification. Intern Med 2000; 39 (3): 253-255.

46. Hassan S, Shaikh MU, Ali N, Riaz M. Copper sulphate toxicity in a young male complicated by methemoglobinemia, rhabdomyolysis and renal failure. J Coll Physicians Surg Pak 2010; 20 (7): 490-491.

47. Rodriguez-Castro KI, Hevia-Urrutia FJ, Sturniolo GC. Wilson's disease: A review of what we have learned. World J Hepatol 2015; 7 (29): 2859-2870.

48. Poujois A, Woimant F. Wilson's disease: A 2017 update. Clin Res Hepatol Gastroenterol 2018; 3 (18): 30046-30049.

49. Arioz C, Li Y, Wittung-Stafshede $P$. The six metal binding domains in human copper transporter, atp7b: Molecular biophysics and diseasecausing mutations. Biometals 2017; 30 (6): 823-840. 
50. Muchenditsi A, Yang H, Hamilton JP et al. Targeted inactivation of copper transporter atp $7 \mathrm{~b}$ in hepatocytes causes liver steatosis and obesity in mice. Am J Physiol Gastrointest Liver Physiol 2017; 313 (1): G39-G49.

51. Shim JO, Yang HR, Moon JS et al. Multiplex ligation-dependent probe amplification analysis subsequent to direct DNA full sequencing for identifying atp $7 \mathrm{~b}$ mutations and phenotype correlations in children with Wilson disease. J Korean Med Sci 2018; 33 (26): 25.

52. Clark-Feoktistova Y, Ruenes-Domech C, Garcia-Bacallao EF et al. Presence of the p.L456v polymorphism in Cuban patients clinically diagnosed with Wilson's disease. Rev Gastroenterol Mex 2018; 10 (18): 30094-30096.

53. Czlonkowska A, Litwin T, Dusek $\mathbf{P}$ et al. Wilson disease. Nat Rev Dis Primers 2018; 4 (1): 018-0018.

54. Nishimuta M, Masui K, Yamamoto T et al. Copper deposition in oligodendroglial cells in an autopsied case of hepatolenticular degeneration. Neuropathology 2018; 38 (3): 321-328.

55. Biswas S, Paul N, Das SK. Nonmotor manifestations of Wilson's disease. Int Rev Neurobiol 2017; 134: 1443-1459.

56. Bansagi B, Lewis-Smith D, Pal E et al. Phenotypic convergence of Menkes and Wilson disease. Neurol Genet 2016; 2 (6).

57. Grupchev DI, Radeva MN, Georgieva M, Grupcheva CN. In vivo confocal microstructural analysis of corneas presenting kayser-fleischer rings in patients with Wilson's disease. Arq Bras Oftalmol 2018; 81 (2): 137-143.

58. Lin LJ, Wang DX, Ding NN, Lin Y, Jin Y, Zheng CQ. Comprehensive analysis on clinical features of Wilson's disease: An experience over 28 years with 133 cases. Neurol Res 2014; 36 (2): 157-163.

59. Van Biervliet S, Kury S, De Bruyne R et al. Clinical zinc deficiency as early presentation of Wilson disease. J Pediatr Gastroenterol Nutr 2015; 60 (4): 457-459.

60. de Gemmis P, Enzo MV, Lorenzetto E, Cattelan P, Segat D, Hladnik U. 13 novel putative mutations in atp7a found in a cohort of 25 italian families. Metab Brain Dis 2017; 32 (4): 1173-1183.

61. Cao B, Yang X, Chen Y et al. Identification of novel atp7a mutations and prenatal diagnosis in chinese patients with menkes disease. Metab Brain Dis 2017; 32 (4): 1123-1131.

62. Skjorringe T, Amstrup Pedersen P, Salling Thorborg S, Nissen P, Gourdon P, Birk Moller L. Characterization of atp 7a missense mutants suggests a correlation between intracellular trafficking and severity of menkes disease. Sci Rep 2017; 7 (1): 017-00618.

63. Horn N, Moller LB, Nurchi VM, Aaseth J. Chelating principles in Menkes and Wilson diseases: Choosing the right compounds in the right combinations at the right time. J Inorg Biochem 2019; 190: 98-112.

64. Nomura S, Nozaki S, Hamazaki T et al. Pet imaging analysis with $64 \mathrm{cu}$ in disulfiram treatment for aberrant copper biodistribution in menkes disease mouse model. J Nucl Med 2014; 55 (5): 845-851.

65. Li WJ, Chen C, You ZF, Yang RM, Wang XP. Current drug managements of Wilson's disease: From west to east. Curr Neuropharmacol 2016; 14 (4): 322-325.

66. Tumer Z. An overview and update of atp7a mutations leading to menkes disease and occipital horn syndrome. Hum Mutat 2013; 34 (3): 417-429.

67. Yasmeen S, Lund K, De Paepe A et al. Occipital horn syndrome and classical menkes syndrome caused by deep intronic mutations, leading to the activation of atp7a pseudo-exon. Eur J Hum Genet 2014; 22 (4): 517-521.
68. Bonati MT, Verde F, Hladnik U et al. A novel nonsense atp7a pathogenic variant in a family exhibiting a variable occipital horn syndrome phenotype. Mol Genet Metab Rep 2017; 13: 14-17.

69. Dagenais SL, Adam AN, Innis JW, Glover TW. A novel frameshift mutation in exon 23 of atp $7 \mathrm{a}$ (mnk) results in occipital horn syndrome and not in menkes disease. Am J Hum Genet 2001; 69 (2): 420-427.

70. Muller T, Muller W, Feichtinger H. Idiopathic copper toxicosis. Am J Clin Nutr 1998; 67 (5 Suppl).

71. Gaur K, Sakhuja P, Mandal RN, Kapoor S. Indian childhood cirrhosis - down but not out: Report of a rare case with a practical clinicopathological diagnostic approach. J Postgrad Med 2018; 64 (2): 104-108.

72. Wijmenga C, Muller T, Murli IS et al. Endemic tyrolean infantile cirrhosis is not an allelic variant of Wilson's disease. Eur J Hum Genet 1998; 6 (6): 624-628.

73. Johncilla M, Mitchell KA. Pathology of the liver in copper overload. Semin Liver Dis 2011; 31 (3): 239-244.

74. Muller T, Feichtinger H, Berger H, Muller W. Endemic tyrolean infantile cirrhosis: An ecogenetic disorder. Lancet 1996; 347 (9005): $877-880$.

75. Pohanka M. Alzheimer's disease and oxidative stress. A review. Curr Med Chem 2014; 21 (3): 356-364.

76. Lane CA, Hardy J, Schott JM. Alzheimer's disease. Eur J Neurol 2017; 4 (10): 13439.

77. Pohanka M. Oxidative stress in alzheimer disease as a target for therapy. Bratisl Lek Listy 2018; 119 (9): 535-543.

78. Trapp GA, Miner GD, Zimmerman RL, Mastri AR, Heston LL. Aluminum levels in brain in alzheimer's disease. Biol Psychiatry 1978; 13 (6): 709-718.

79. Delaney JF. Spinal fluid aluminum levels in patients with alzheimer disease. Ann Neurol 1979; 5 (6): 580-581.

80. Shore D, Millson M, Holtz JL, King SW, Bridge TP, Wyatt RJ. Serum aluminum in primary degenerative dementia. Biol Psychiatry 1980; 15 (6): 971-977.

81. Inan-Eroglu E, Ayaz A. Is aluminum exposure a risk factor for neurological disorders? J Res Med Sci 2018; 23 (51).

82. Tomljenovic L. Aluminum and Alzheimer's disease: After a century of controversy, is there a plausible link? J Alzheimers Dis 2011; 23 (4): $567-598$.

83. Hussien HM, Abd-Elmegied A, Ghareeb DA, Hafez HS, Ahmed HEA, El-Moneam NA. Neuroprotective effect of berberine against environmental heavy metals-induced neurotoxicity and alzheimer's-like disease in rats. Food Chem Toxicol 2018; 111: 432-444.

84. Chakraborty P. Mercury exposure and Alzheimer's disease in india - an imminent threat? Sci Total Environ 2017; 589: 232-235.

85. Morris DR, Levenson CW. Neurotoxicity of zinc. Adv Neurobiol 2017; 18: 303-312.

86. Yang YW, Liou SH, Hsueh YM et al. Risk of Alzheimer's disease with metal concentrations in whole blood and urine: A case-control study using propensity score matching. Toxicol Appl Pharmacol 2018; 356: $8-14$.

87. Mathys ZK, White AR. Copper and Alzheimer's disease. Adv Neurobiol 2017; 18: 199-216. 
88. Zhao J, Gao W, Yang Z, Li H, Gao Z. Nitration of amyloid-beta peptide (1-42) as a protective mechanism for the amyloid-beta peptide (1-42) against copper ion toxicity. J Inorg Biochem 2019; 190: 15-23.

89. Bolognin S, Messori L, Drago D, Gabbiani C, Cendron L, Zatta P. Aluminum, copper, iron and zinc differentially alter amyloid-abeta(1-42) aggregation and toxicity. Int J Biochem Cell Biol 2011; 43 (6): 877-885.

90. Grasso G, Pietropaolo A, Spoto G et al. Copper(i) and copper(ii) inhibit abeta peptides proteolysis by insulin-degrading enzyme differently: Implications for metallostasis alteration in alzheimer's disease. Chemistry 2011; 17 (9): 2752-2762.

91. Grasso G, Salomone F, Tundo GR et al. Metal ions affect insulindegrading enzyme activity. J Inorg Biochem 2012; 117: 351-358.

92. Choudhury GR, Daadi MM. Charting the onset of Parkinson-like motor and non-motor symptoms in nonhuman primate model of Parkinson's disease. PLoS One 2018; 13 (8).

93. Emamzadeh FN. Role of apolipoproteins and alpha-synuclein in Parkinson's disease. J Mol Neurosci 2017; 62 (3-4): 344-355.

94. Ghosh D, Mehra S, Sahay S, Singh PK, Maji SK. Alpha-synuclein aggregation and its modulation. Int J Biol Macromol 2017; 100: 37-54.

95. Dickson DW. Neuropathology of Parkinson disease. Parkinsonism Relat Disord 2018; 46 (1): S30-S33.

96. Ho Y J, Weng JC, Lin CL et al. Ceftriaxone treatment for neuronal deficits: A histological and memri study in a rat model of dementia with lewy bodies. Behav Neurol 2018; 1 (4618716).

97. Irwin DJ, Hurtig HI. The contribution of tau, amyloid-beta and alphasynuclein pathology to dementia in lewy body disorders. J Alzheimers Dis Parkinsonism 2018; 8 (4): 2161-0460.

98. Rodriguez L, Marano MM, Tandon A. Import and export of misfolded alpha-synuclein. Front Neurosci 2018; 12 (344).

99. Melki R. Alpha-synuclein and the prion hypothesis in Parkinson's disease. Rev Neurol 2018; 174 (9): 644-652.

100. Kasai T, Tokuda T, Yamaguchi $\mathbf{N}$ et al. Cleavage of normal and pathological forms of alpha-synuclein by neurosin in vitro. Neurosci Lett 2008; 436 (1): 52-56.

101. Chartier S, Duyckaerts C. Is lewy pathology in the human nervous system chiefly an indicator of neuronal protection or of toxicity? Cell Tissue Res 2018; 373 (1): 149-160.

102. Gorell JM, Johnson CC, Rybicki BA et al. Occupational exposure to manganese, copper, lead, iron, mercury and zinc and the risk of Parkinson's disease. Neurotoxicology 1999; 20 (2-3): 239-247.

103. Gorell JM, Johnson CC, Rybicki BA et al. Occupational exposures to metals as risk factors for Parkinson's disease. Neurology 1997; 48 (3): 650-658.

104. Willkommen D, Lucio M, Schmitt-Kopplin P et al. Species fractionation in a case-control study concerning Parkinson's disease: $\mathrm{Cu}$-amino acids discriminate csf of pd from controls. J Trace Elem Med Biol 2018; 49: 164-170.

105. Karpenko MN, Ilyicheva EY, Muruzheva ZM, Milyukhina IV, Orlov YA, Puchkova LV. Role of copper dyshomeostasis in the pathogenesis of Parkinson's disease. Bull Exp Biol Med 2018; 164 (5): 596-600.

106. Abbaoui A, Gamrani H. Neuronal, astroglial and locomotor injuries in subchronic copper intoxicated rats are repaired by curcumin: A possible link with Parkinson's disease. Acta Histochem 2018; 120 (6): 542-550.
107. McLeary FA, Rcom-H'cheo-Gauthier AN, Kinder J et al. Dexamethasone inhibits copper-induced alpha-synuclein aggregation by a metallothionein-dependent mechanism. Neurotox Res 2018; 33 (2): 229238.

108. Ilyechova EY, Miliukhina IV, Orlov IA, Muruzheva ZM, Puchkova LV, Karpenko MN. A low blood copper concentration is a comorbidity burden factor in Parkinson's disease development. Neurosci Res 2018; 135: 54-62.

109. Kim MJ, Oh SB, Kim J et al. Association of metals with the risk and clinical characteristics of Parkinson's disease. Parkinsonism Relat Disord 2018; 55: 117-121.

110. Pohanka M. Role of oxidative stress in infectious diseases. A review. . Folia Microbiol 2013; 58 (6): 503-513.

111. Wang Q, Ma Y, Xing S. Comparative study of cu-based bimetallic oxides for fenton-like degradation of organic pollutants. Chemosphere 2018; 203: 450-456.

112. Saporito-Magrina C, Musacco-Sebio R, Acosta JM et al. Copper(ii) and iron(iii) ions inhibit respiration and increase free radical-mediated phospholipid peroxidation in rat liver mitochondria: Effect of antioxidants. J Inorg Biochem 2017; 172: 94-99.

113. Dorotikova S, Koziskova J, Malcek M et al. Copper(ii) complexes with new fluoroquinolones: Synthesis, structure, spectroscopic and theoretical study, DNA damage, cytotoxicity and antiviral activity. J Inorg Biochem 2015; 150: 160-173.

114. Kehrer JP. The haber-weiss reaction and mechanisms of toxicity. Toxicology 2000; 149 (1): 43-50.

115. Koppenol WH. The haber-weiss cycle--70 years later. Redox Rep 2001; 6 (4): 229-234.

116. Du Y, Wu QY, Lv XT, Wang QP, Lu Y, Hu HY. Exposure to solar light reduces cytotoxicity of sewage effluents to mammalian cells: Roles of reactive oxygen and nitrogen species. Water Res 2018; 143 : $570-578$.

117. Gabe Y, Miyaji A, Kohno M, Hachiya A, Moriwaki S, Baba T. Substantial evidence for the rhododendrol-induced generation of hydroxyl radicals that causes melanocyte cytotoxicity and induces chemical leukoderma. J Dermatol Sci 2018; 91 (3): 311-316.

118. Prosdocimi T, De Gioia L, Zampella G, Bertini L. On the generation of oh(.) radical species from $\mathrm{h} 2 \mathrm{o} 2$ by cu(i) amyloid beta peptide model complexes: A dft investigation. J Biol Inorg Chem 2016; 21 (2): 197-212.

119. Cheignon C, Tomas M, Bonnefont-Rousselot D, Faller P, Hureau C, Collin F. Oxidative stress and the amyloid beta peptide in alzheimer's disease. Redox Biol 2018; 14: 450-464.

120. Tambosi R, Liotenberg S, Bourbon ML et al. Silver and copper acute effects on membrane proteins and impact on photosynthetic and respiratory complexes in bacteria. mBio 2018; 9 (6): 01535-01518.

121. Tarrant E, G PR, McIlvin MR et al. Copper stress in staphylococcus aureus leads to adaptive changes in central carbon metabolism. Metallomics 2018; 16 (10).

122. Oladipo OG, Burt AF, Maboeta MS. Effect of bacillus cereus on the ecotoxicity of metal-based fungicide spiked soils: Earthworm bioassay. Ecotoxicology 2018; 14 (10): 018-1997.

123. Cornu JY, Huguenot D, Jezequel K, Lollier M, Lebeau T. Bioremediation of copper-contaminated soils by bacteria. World J Microbiol Biotechnol 2017; 33 (2): 016-2191. 
124. Brunetto G, Bastos de Melo GW, Terzano R et al. Copper accumulation in vineyard soils: Rhizosphere processes and agronomic practices to limit its toxicity. Chemosphere 2016; 162: 293-307.

125. Adrees M, Ali S, Rizwan M et al. The effect of excess copper on growth and physiology of important food crops: A review. Environ Sci Pollut Res Int 2015; 22 (11): 8148-8162.

126. Pohanka M. Copper, aluminum, iron and calcium inhibit human acetylcholinesterase in vitro. Environ Toxicol Pharmacol 2014; 37 (1): 455-459.

127. Chen Z, Mayer LM, Weston DP, Bock MJ, Jumars PA. Inhibition of digestive enzyme activities by copper in the guts of various marine benthic invertebrates. Environ Toxicol Chem 2002; 21 (6): 1243-1248.

128. Jorge MB, Lauer MM, Martins Cde M, Bianchini A. Impaired regulation of divalent cations with acute copper exposure in the marine clam mesodesma mactroides. Comp Biochem Physiol C Toxicol Pharmacol 2016; 179: 79-86.

129. Liu J, Zhao H, Wang Y, Shao Y, Zhang L, Xing M. Impacts of simultaneous exposure to arsenic (iii) and copper (ii) on inflammatory response, immune homeostasis, and heat shock response in chicken thymus. Int Immunopharmacol 2018; 64: 60-68.

130. Cholewinska E, Juskiewicz J, Ognik K. Comparison of the effect of dietary copper nanoparticles and one copper (ii) salt on the metabolic and immune status in a rat model. J Trace Elem Med Biol 2018; 48: 111-117.

131. Bleidorn J, Alamzad-Krabbe H, Gerhards B et al. The pro-inflammatory stimulus of zinc- and copper-containing welding fumes in whole blood assay via protein tyrosine phosphatase 1b inhibition. Sci Rep 2019; 9 (1): 018-37803.

132. Krabbe J, Esser A, Kanzler S et al. The effects of zinc- and coppercontaining welding fumes on murine, rat and human precision-cut lung slices. J Trace Elem Med Biol 2018; 49: 192-201.

133. Yee EMH, Brandl MB, Pasquier E et al. Dextran-catechin inhibits angiogenesis by disrupting copper homeostasis in endothelial cells. Sci Rep 2017; 7 (1): 017-07452.

134. Magri A, Grasso G, Corti F et al. Peptides derived from the histidine-proline rich glycoprotein bind copper ions and exhibit anti-angiogenic properties. Dalton Trans 2018; 47 (28): 9492-9503.

135. Shobha Devi C, Thulasiram B, Aerva RR, Nagababu P. Recent advances in copper intercalators as anticancer agents. J Fluoresc 2018; 28 (5): 1195-1205

136. Hassani S, Ghaffari P, Chahardouli B et al. Disulfiram/copper causes ros levels alteration, cell cycle inhibition, and apoptosis in acute myeloid leukaemia cell lines with modulation in the expression of related genes. Biomed Pharmacother 2018; 99: 561-569.

137. Denoyer D, Clatworthy SAS, Cater MA. Copper complexes in cancer therapy. Met Ions Life Sci 2018; 9783110470734 : $9783110470734-$ 9783110470022 .

138. Wang S, Lv J, Zhang S. Discovery of crr1-targeted copper deficiency response in chlamydomonas reinhardtii exposed to silver nanoparticles. Nanotoxicology 2019; 1: 1-8.

139. Chen C, Cheng S, Shi T et al. Size distribution control of copper nanoparticles and oxides: Effect of wet-chemical redox cycling. Inorg Chem 2019; 31 (10).

140. Henam SD, Ahmad F, Shah MA, Parveen S, Wani AH. Microwave synthesis of nanoparticles and their antifungal activities. Spectrochim Acta A Mol Biomol Spectrosc 2019; 213: 337-341.
141. Tang Y, Liu M, Zhao Z et al. Fluorometric determination of microrna-122 by using exoiii-aided recycling amplification and polythymine induced formation of copper nanoparticles. Mikrochim Acta 2019; 186 (3): 019-3237.

142. Khanna L, Gupta G, Tripathi SK. Effect of size and silica coating on structural, magnetic as well as cytotoxicity properties of copper ferrite nanoparticles. Mater Sci Eng C Mater Biol Appl 2019; 97: 552-566.

143. Kim HE, Lee HJ, Kim MS et al. Differential microbicidal effects of bimetallic iron-copper nanoparticles on escherichia coli and ms 2 coliphage. Environ Sci Technol 2019; 30 (10).

144. Jayaramudu T, Varaprasad K, Pyarasani RD et al. Chitosan capped copper oxide/copper nanoparticles encapsulated microbial resistant nanocomposite films. Int J Biol Macromol 2019; 128: 499-508.

145. Hejazy M, Koohi MK, Pour ABM, Najafi D. Toxicity of manufactured copper nanoparticles - a review. Nanomed Res J 2018; 3 (1): 1-9.

146. Han PF, Martens W, Waclawik ER, Sarina S, Zhu HY. Metal nanoparticle photocatalysts: Synthesis, characterization, and application. Part Part Syst Charact 2018; 35 (6).

147. Dabagh S, Chaudhary K, Haider Z, Ali J. Effect of sintering on di-electric characteristics of al-cu doped cobalt ferrite nanoparticles. J Nanosci Nanotechnol 2019; 19 (7): 4142-4146.

148. Yu JH, Jung HS, Jeong JK, Kang KT. Sintering behavior of copper nanoparticle ink by laser in air. J Nanosci Nanotechnol 2019; 19 (3): 1261-1268.

149. Banthia S, Sengupta S, Das S, Das K. Synthesis and characterization of novel cu, cu-sic functionally graded coating by pulse reverse electrodeposition. Appl Surf Sci 2019; 467: 567-579.

150. Sreeju N, Rufus A, Philip D. Nanostructured copper (ii) oxide and its novel reduction to stable copper nanoparticles. J Phys Chem Solids 2019; 124: 250-260.

151. Azarifar D, Mahmoudi-Gom Yek S, Ghaemi M. Immobilized cu(ii) schiff base complex supported on fe 304 magnetic nanoparticles: A highly efficient and reusable new catalyst for the synthesis of pyranopyridine derivatives. Appl Organomet Chem 2018; 32 (12).

152. Chandra S, Kumar A, Tomar PK. Synthesis and characterization of copper nanoparticles by reducing agent. J Saud Chem Soc 2014; 18 (2): 149-153.

153. Zain NM, Stapley AG, Shama G. Green synthesis of silver and copper nanoparticles using ascorbic acid and chitosan for antimicrobial applications. Carbohydr Polym 2014; 112: 195-202.

154. Ren G, Hu D, Cheng EW, Vargas-Reus MA, Reip P, Allaker RP. Characterisation of copper oxide nanoparticles for antimicrobial applications. Int J Antimicrob Agents 2009; 33 (6): 587-590.

155. Miao L, Wang P, Hou J, Yao Y, Liu Z, Liu S. Low concentrations of copper oxide nanoparticles alter microbial community structure and function of sediment biofilms. Sci Total Environ 2019; 653: 705-713.

156. Guo Y, Cao F, Lei X, Mang L, Cheng S, Song J. Fluorescent copper nanoparticles: Recent advances in synthesis and applications for sensing metal ions. Nanoscale 2016; 8 (9): 4852-4863.

157. Bharathi D, Krishna RH, Siddlingeshwar B, Divakar DD, Alkheraif AA. Understanding the interaction of carbon quantum dots with cuo and cu2o by fluorescence quenching. J Hazard Mater 2019; 369: 17-24.

158. Fan K, Kang W, Qu S, Li L, Qu B, Lu L. A label-free and enzymefree fluorescent aptasensor for sensitive detection of acetamiprid based on at-rich dsdna-templated copper nanoparticles. Talanta 2019; 197: 645-652. 
159. Wang N, Dai H, Sai L, Ma H, Lin M. Copper ion-assisted gold nanoparticle aggregates for electrochemical signal amplification of lipopolysaccharide sensing. Biosens Bioelectron 2018; 126: 529-534.

160. Zhang L, Ye C, Li $X$ et al. A cuni/c nanosheet array based on a metal-organic framework derivate as a supersensitive non-enzymatic glucose sensor. Nanomicro Lett 2018; 10 (2): 017-0178.

161. Long D, Chen C, Cui C, Yao Z, Yang P. A high precision mua-spaced single-cell sensor for cellular receptor assay based on bifunctional au@ cu-pbcqd nanoprobes. Nanoscale 2018; 10 (39): 18597-18605.

162. Ahamed M, Akhtar MJ, Alhadlaq HA, Alrokayan SA. Assessment of the lung toxicity of copper oxide nanoparticles: Current status. Nanomedicine 2015; 10 (15): 2365-2377.

163. Chen Z, Meng H, Xing G et al. Acute toxicological effects of copper nanoparticles in vivo. Toxicol Lett 2006; 163 (2): 109-120.

164. Torres-Duarte C, Hutton S, Vines C, Moore J, Cherr GN. Effects of soluble copper and copper oxide nanoparticle exposure on the immune system of mussels, mytilus galloprovincialis. Environ Toxicol 2018; 2 (10): 22684.

165. Liu J, Dhungana B, Cobb GP. Environmental behavior, potential phytotoxicity, and accumulation of copper oxide nanoparticles and arsenic in rice plants. Environ Toxicol Chem 2018; 37 (1): 11-20.
166. Rajput V, Minkina T, Fedorenko A et al. Toxicity of copper oxide nanoparticles on spring barley (hordeum sativum distichum). Sci Total Environ 2018; 645: 1103-1113.

167. Wyman AE, Hines SE. Update on metal-induced occupational lung disease. Curr Opin Allergy Clin Immunol 2018; 18 (2): 73-79.

168. Lai X, Zhao H, Zhang $Y$ et al. Intranasal delivery of copper oxide nanoparticles induces pulmonary toxicity and fibrosis in c $57 \mathrm{bl} / 6 \mathrm{mice}$. Sci Rep 2018; 8 (1): 018-22556.

169. Gosens I, Cassee FR, Zanella $M$ et al. Organ burden and pulmonary toxicity of nano-sized copper (ii) oxide particles after short-term inhalation exposure. Nanotoxicology 2016; 10 (8): 1084-1095.

170. Hu S, Yang J, Rao M et al. Copper nanoparticle-induced uterine injury in female rats. Environ Toxicol 2018; 16 (10): 22680.

171. De Jong WH, De Rijk E, Bonetto A et al. Toxicity of copper oxide and basic copper carbonate nanoparticles after short-term oral exposure in rats. Nanotoxicology 2018; 19: 1-23.

Received March 18, 2019. Accepted April 22, 2019. 